\title{
Jenseits der Mauer: \\ A Tragic Untragedy
}

By Mathew Duerden

his paper will utilize Nietzsche's views on the relationship
between tragedy and the Apollonian and Dionysian drives to evaluate the character of Jutta von Hadersloh in Elisabeth Heinroth's novel Jenseits der Mauer. Nietzsche first presented his idea of Apollonian and Dionysian forces in the book The Birth of Tragedy. His theory developed as a response to contemporary analyses of Greek art and literature (Sweet 347). Nietzsche argued that two major forces existed in art and in life itself, which he dubbed the Apollonian and the Dionysian. The Apollonian side represents individuality, logic, reason, and form, the "edle Einfalt und Stille Grösse" apparent in many pieces of Greek art (Sweet 347). The Dionysian side represents collectiveness, nature, formlessness, rage, passion, and raw emotions.

Nietzsche proposed that to obtain true harmony, both the Apollonian and the Dionysian drives must exist together. David 


\section{A Tragic Untragedy}

Lenson sums up Nietzsche's theory accordingly: “And so the relationship of these two gods, the embodiments of two modes of being, is certainly not dialectical opposition after all. It is more like symbiosis, or mutual dependency" (48). The Apollonian provides a form in which the formless Dionysian can reside.

An analogy can be drawn to how a light bulb works; the light bulb itself provides a structure that can contain electricity, and together they create light. A light bulb without electricity or electricity without a light bulb produces nothing. The same applies to the Apollonian and Dionysian when separated; Nietzsche felt when they combine, true tragedy is born (Sweet 357).

Jutta von Hadersloh, upon first examination, has all the makings of a true tragic figure. In the first volume of this two volume story, Jutta possesses both strong Apollonian and Dionysian drives. As volume two progresses, Jutta struggles with balancing these two natures. In the end she casts aside her Apollonian individuality and descends into the Dionysian collectiveness, thus becoming a very "untragic" character.

When Luise meets Jutta at her rejuvenated Eicken estate she believes that her old schoolmate leads a balanced life. The prosperity she sees around her quickly dissipates any doubts that her aunt had previously put her in head: "da sollen auch seltsame, sehr seltsame Dinge auf Eicken passiert sein" (Heinroth 1:7). Jutta exudes confidence; a woman with a very strong Apollonian nature. Her decision to take over control of her husband's estate after his death illustrates this. Not only does she salvage the estate, but she manages to turn it into one of the most profitable areas in that part of the country. The god Apollo was recognized for his creative power and ability to mold physical things 


\section{A Tragic Untragedy}

(Lenson 33). Jutta also possesses this innovative quality; she is respected throughout the countryside for successfully managing her estate. In fact, Herr Gervissen had heard much about Frau von Hadersloh after having been in the area for only a short while: "diese Gutsfrau von Eicken [Jutta], das mu_ ein famoses Frauenzimmer sein. Eine äu_erst tatkräftige Geschäftsfrau, Gutsherrin in gro_en Stil' (Heinroth 1:3). Jutta's ability to handle her estate is so superb Gervissen can't help notice, even though she is a female.

Along with these characteristics she exhibits other strong Apollonian personality traits not usually attributed to female literary figures from the nineteenth-century. She loves to learn and passes this desire on to her children; even her daughter is preparing to learn Latin. She also handles all accidents on her estate as Hortmann, her second in command, cannot stand the sight of blood. There is no task which she views as impossible; she has risen to great heights through hard work and common sense. All these traits add to her self-confidence, creating a strong Apollonian outward form.

Jutta prides herself in outward appearances. She dresses with style, and decorates her house to reflect her own individual tastes: "Die Zimmereinrichtung war aus behablichen, neumodischen Korbmöbeln . . . das hatte früber alles halb zerfallen mit mottenzerfressenen Polstern auf dem Boden gestanden; jetrt. . . machte es einen äu_erst stilvollen Eindruck. . .” (Heinroth 1:26-27). Jutta successfully revitalizes a decaying atmosphere, giving it a new form.

Jutta's strong Apollonian nature also houses some very passionate Dionysian impulses. The book itself begins with Dionysian tones in its description of the countryside in early spring: "Vorfrübling in der Heide. Ein leiser Wind strich über die wellige braune Ebene dahin, ein Wind, der bei all seiner Frische doch schon einen 


\section{A Tragic Untragedy}

Hauch der Wärme mit sich führte (Heinroth 1:1). Nature, especially the death and rebirth associated with spring, are strong Dionysian elements. Lenson makes the following comment concerning this relationship: "Dionysus is above all an agrarian god. He is ritually dismembered in the fall and reborn in the spring, an emblematic divinity embodying human dependency upon the seasons, especially among farmers" (25-26). Jutta shares an intimate bond with the land and nature. She revels in her small kingdom and her agrarian successes. Jutta's description to Luise of her personal relationship with the land reveals the Dionysian side of her personality:

Ja, siehst du, es ist ganz merkwürdig, wie wir in einem Boden festwachsen, der unsere Tränen und unseren Schwei_ getrunken hat. Wo wir sehr viel gelitten und gekämpft haben, wo wir's uns sehr sauer haben werden lassen, da pflanzen wir unvermerkt eine gro_e, hei_e, still Liebe mit der Not und Arbeit in den hungrigen Boden hinein. Er ist ein Stück unseres Lebens geworden (Heinroth1:21-22).

Jutta, like Dionysus, gives part of herself to the land as she assists with its annual rebirth.

At this point in the novel it seems that Jutta has established a harmonious balance between the Apollonian and Dionysian drives in her life. She is successful, powerful, and well-respected. While sitting with Jutta and her friend Klaus Börcke, Luise notices the harmony that seems to radiate from Jutta and everything she comes in contact with, including her manor: “. . . die reinen, sü_en Klänge Mozarts tönten durch den Raum . . . . Die weichen Tonwellen glitten über die anbeimelnd schlichten Geräten ... als ob sie eine klingende Ausströmung dieser Dinge wären, so selbstverständlich harmonisch dazugehörig" (Heinroth 1:32). Jutta believes that she has 


\section{A Tragic Untragedy}

attained perfect harmony in her life. But one Dionysian drive threatens to break out of its Apollonian encasement and destroy what harmony exists.

Before Luise comes to Eicken, her aunt warns her that Jutta is "eine Frau von freien --- aber sehr freien Sitten . .." (Heinroth 1:7). The fact that Jutta does not feel restricted by society's morals would not have affected her personal Apollonian/Dionysian balance. Instead, an imbalance begins to arise because for Jutta, love is an entirely Dionysian experience. This becomes clear from the description of Jutta's first kiss with Herr Gervissen: " $d a$ kam ein wunderbar seliges Vergessen über die schöne Frau von Hadersloh. Alles Vergangene, alles schon Durchlebte vesank in graues Nichts" (Heinroth 1:75). This account of Jutta and Gervissen's kiss resembles Lenson's description of the effect of Dionysian art: "For the art of intoxication dissolves the individual into the body of collective consciousness, where the self no longer has any meaning" (48). Jutta never loves her lovers; she loves love itself, in its pure emotional form. Men are simply the means through which she experiences this emotion. In fact, the embodiment of love in the form of a man almost doesn't appeal to her; she loves the ambiguous form of love, a very Dionysian impulse considering "Dionysian [is] the formless source of the transitory formalism of Apollo" (Lenson 43).

As soon as men start becoming more powerful than her emotions in any one of Jutta's relationships Jutta immediately removes all of her passion, reducing the relationship to mere friendship. Whenever the Apollonian world begins to give form to her Dionysian love affairs she cuts them short: "Vor keinem Zustand graute ihr mehr, als vor einem Abflauen der Liebe in das seichte Gewässer gewohnbeitsmässiger Sinnenbefriedigung” (Heinroth 1:78). 


\section{A Tragic Untragedy}

Klaus Börcke experienced this first hand as he made the transition from lover to purely platonic friend. Jutta does not know how to love love and a man at the same time.

The affair with Herr Gervissen is the first instance in the story where Jutta's unbalanced nature becomes apparent. Love represents the one area where Jutta completely casts off all Apollonian tendencies, and revels in the Dionysian. Her attitude towards love creates disharmony between the two drives in her life, and leads to her eventual break with Apollonian.

Jutta begins to build a wall between her Dionysian and Apollonian halves because of her inability to become part of balanced relationship. This wall eventually cuts the two sides off from each other completely. The reality she creates for herself becomes unstable because of this wall. Jenseits der Mauer deals with the issues of walls in its characters' lives. The novel's other characters face walls imposed by outside forces. Jutta, who prides herself in her individuality, suffers because of the wall she builds for herself between her Apollonian and Dionysian drives.

The separation between these two drives beings to weaken her as a character. For the first time she begins to experience doubts about herself. She attends a ball with Otti, and hears other ladies speaking about her unchaste way in sin-hushed tones. Later, in the beginning of volume two, she struggles with how she can dissuade Otti from having any affair, when the young girl is simply following her example. In the midst of these questions and worries, Jutta leaves for Berlin.

Berlin, for Jutta, represents a major change in her life. She leaves the confines of Eicken, the center of her world, and travels to the center of Germany's cultural world. She no longer 


\section{A Tragic Untragedy}

stands as the center of all things important. Coupled with instability growing within her at the end of volume one, a move to Berlin puts her on very uneasy emotional ground. This uneasiness only helps to intensify the growing conflict between Dionysian and Apollonian drives.

Eicken represents nature, love, and power to Jutta, all very Dionysian concepts. Nothing could contrast with Eicken more than Berlin, with its form, structure and strong Apollonian undertones. She leaves her Dionysian comfort zone, and comes to the big Apollonian city. This shift of environments forces her to confront the internal struggle from which she had intended to flee. Widening the rift between her two emotional sides, the new environment causes her to cling more closely to her Dionysian side.

At this point in the novel she has not yet completely given in to the Dionysian. Individuality still remains an important thing to Jutta. She is a woman who lives how she wants to live, regardless of what others think. The Dionysian "collective conscious" discussed earlier does not yet appeal to her. As she walks through the teeming streets of Berlin she struggles to maintain a sense of identity, as if the Dionysian world is closing in around her. Amidst all the confusion of the city she notices the Kaiser-Wilhelm-Gedächtnis church, which calms her because of its individuality amongst all the confusion: "Der Anblick machte Jutta seltsam frob und sicher. Als ob ibr eigenes persönliches Schickesal sie wieder umschlösse, dem sie für eine kurz̨e Weile entglitten war. Sie füblte sich nicht mehr als Schatten unten Schattenbildern. Sie war wieder Mittelpunkt der Welt geworden" (Heinroth 2:74). Jutta has spent a large portion of her life enforcing her individuality, and it unnerves her to fell that there are forces that could take it 


\section{A Tragic Untragedy}

from her.

Her interaction with Dr. Frentzius' Neu-Ethiker friends also causes Jutta to reflect on individuality. She cannot understand their desire to force their own personal moral philosophy upon others. Although she lives a morally free life, she feels no need to force her ways on others. How each person lives life is, in her mind, a very personal decision. When confronted by Luise concerning her questionable morals Jutta merely answers that she does what feels natural: "Es ist ja alles so ganz, natürlich, was ich tue und nicht tue" (Heinroth 1:88). By siding with the Neu-Ethike group Jutta would be forced to surrender a part of herself. Even though it has strong Dionysian undertones, such surrender does not appeal to her nature. Her desire to hold to her individuality delays her eventual submission to the Dionysian, and almost allows her to become a tragic character.

The single most important event that occurs during Jutta's stay in Berlin is her introduction to Herger. He is the first man that Jutta is not able to gain complete control over. She finds herself submitting herself to his control after spending an evening in his company: "Zum erstenmal in ibrem Leben beugte die schöne Frau von Hadersloh ibr Haupt vor dem Schicksal, zum erstenmal stand sie da als inbrünstig Bittende" (Heinroth 2:89). This encounter with such foreign feelings foreshadows that Jutta will some face some important decisions.

Herger represents everything that Jutta desires in a man. She finds herself attracted to him not simply to be attracted, but because of who he is. She has the opportunity to truly love a person, not simply the feeling of being in love. Herger also sees in Jutta the embodiment of the woman he has always wanted to find. The one hindrance to their whole relationship lies in the 


\section{A Tragic Untragedy}

question of Jutta's personal purity. Herger's strict moral code, in contrast to Jutta's free lifestyle, only allows him to marry a pure woman. Jutta never considers that her moral past might jeopardize her eventual marriage with Herger until she receives his letter in which he asks her if she is morally pure.

It is at this point in the novel where everything comes to bear upon Jutta. She returns home to Eicken after her eventful stay in Berlin. She has had to battle the imbalance between her Apollonian and Dionysian drives, struggle to maintain her individuality, deal with Otti's suicide, and learn how to love and lose a man wholeheartedly. Even though she feels no guilt for her past actions, she must decide how to approach Herger, and prepare herself to face any associated consequences. For her to become a tragic character in this instant she would have needed to make a decision which could be integrated by both her Apollonian and Dionysian parts. Such a decision would have strengthened her position as an individual; she instead decides to retreat within her Dionysian world.

After reading Herger's letter Jutta begins her descent into the Dionysian. The shock of the letter causes her to stop struggling to maintain balance between the two drives. The imagery as Jutta finishes the letter and looks out towards the forest symbolically represents the decline of Apollo, the son god, and the rise of Dionysus: "Dort [in dem Kieferwald] war eben die Sonne versunken. Alle Wärme hatte sie mit sich genommen; und ein Schauer flog durch die Natur, etwas Kaltes, Feindseliges" (Heinroth 2:196). The following day Jutta accepts a hunting invitation from her past lover, now friend, Klaus Börcke. The Dionysian imagery increases as they head into the Heide early in the morning:

Von fernher scholl der meckernde Ruf der Bekassinen, dann 


\section{A Tragic Untragedy}

das Pfeifen des Pipers im Moor, das Flöten der Drossel und in dieses helle Konzert stimmte ein dumpfer Klageton ein, der aus dem Föhrengehölz herüberdrang; so äu_erste die Ohreule ihre Gefühle. Es flatterte durch die Luft, es regte sich im Heidekraut (Heinroth 2:203).

As they travel she struggles with the decision she must make. She must choose between defending her life and her decisions, attempting to reconcile herself with Herger, or completely giving in to the Dionysian. As the day begins, and night flees, Jutta is faced by the sun, the symbol of Apollo, whose influence she is attempting to cast off. The new day holds no appeal for her; she has made her decision to reject the Apollonian: "Heute schreckte sie zurück vor dem aufglühende Tage” (Heinroth 2:204).

She realizes that she can't restore her life to how it used to be before she met Herger. The individuality that she has worked so hard to create for herself cannot give her what she desperately wants: a meaningful relationship with Herger. She bitterly casts off her former self and begins her Dionysian descent, finalizing the decision by killing a rooster that Klaus refuses to shoot. This act symbolizes her sacrifice and rebirth, two essential elements of ancient Dionysian rituals; Jutta symbolically kills her Apollonian self and is reborn in a Dionysian form. She then returns home and writes to Herger that she is not the pure woman that he desires. She does not write that she cannot become such a woman or even that she does not want to be such a woman, simply that she is not such a woman. Her descent into the Dionysian collectiveness immobilizes any future progression she might have made. Jutta leaves the letter and is enveloped in the Dionysian as the book closes:

Sie Schlo_ den Brief und trat an das Fenster... . Vom frish 


\section{A Tragic Untragedy}

gepflügten Acker her wehte ein kräftiger Wind. Der Atem der Scholle stieg zu der einsamen Frau empor und neue Kraft erfüllte iher Seele. Ein Glück lag zertrümmert zu ihren Fü_en, das kostbarste, am hei_esten ersehnte . . . aber dort drau_en breitete die Natur ihre unendliche Fülle aus, das unerschöpfliche, starke Leben (Heinroth 2:206).

Why is this not a tragedy? Why is Jutta not a tragic character? Oscar Mandel describes tragedy accordingly: "tragedy asserts more than 'that men [and women] are not happy'; it asserts that they die and are not happy through their own efforts. And not as a mere outcome of their own efforts, but necessarily as a condition contained in the effort" (23-24). According to this definition Jutta seems to be a tragic character. The problem is that Jutta rejects tragedy itself. She casts off the Apollonian; she rejects the "mutual dependency" (Lenson 48) between Apollonian and Dionysian which make tragedy possible. She ceases to progress as an individual.

Integral to a tragic character is their progression through change. In the last pages of the book Jutta slowly loses her individuality, and with it the ability to change and progress. Lenson equates the loss of individuality with an immersion into the Dionysian: "Apollonian art has heretofore been characterized as individualistic . . the solitary figure in the storm-tossed boat, while Dionysian art has been characterized by the submersion of the individual ego in orgiastic song" (51).

Jenseits der Mauer presents a strong-willed character, Jutta von Hadersloh, who weakens as the novel progresses. The story begins with her having some balance between her Apollonian and Dionysian drives, but what starts as a small rift grows until it completely alienates the two impulses from each other. As a 


\section{A Tragic Untragedy}

result she loses the ability to experience tragedy and her own personal individuality as she descends into the Dionysian: "The Dionysian moves from the individual to the collective, whereas the Apollonian goes in the opposite direction" (Lenson 52). Jutta finds herself at novel's end not in a state of tragic progression, but rather in a state of untragic stagnation. 


\section{A Tragic Untragedy}

\section{Works Cited}

Heinroth, Elisabeth. Jenseits der Mauer.

http://humanities.byu.edu/sophie/Heinroth/index.htm

Lenson, David. The Birth of Tragedy: A Student's Companion to the Text. Boston: Twayne, 1987.

Mandel, Oscar. A Definition of Tragedy. New York: New York U P, 1961.

Sweet, Dennis. "The Birth of The Birth of Tragedy." Journal of the History of Ideas 60 (1999): 345-59. 